themselves, among whom there were no excess deaths from leukaemia and only a limited suggestion of an association of death from leukaemia with dose of ionising radiation when considering a lag period of 15 years. ${ }^{21}$ However, if these results have causal significance then they are of much importance to radiological protection of potential parents and their children.

We thank the registration division of the Office of Population Censuses and Surveys, the West Cumbria Health Authority, the Cumbrian Family Practitioner Committee, and other sources mentioned in the text for their cooperation in identifying records on subjects included in the study; the National Health Service central register for providing follow up and tracing details and, with the generous collaboration of local general practitioners, for forwarding questionnaires to parents; the parents for completing them; the Ordnance Survey and British Nuclear Fuels for making relevant information available to us; and many staff of the Medical Research Council Environmental Epidemiology Unit for their help, particularly Mick Merwood, Carol Wickham, and Paul Winter for computer analyses and Gill Strange for preparing the manuscript. Professor Geoffrey Rose kindly commented on an earlier version of the paper, and Professor Peter Smith and Allison Douglas helped with a sample check of the radiation dosimetry data. The study was approved by the British Medical Association ethical committee and the West Cumbria ethics of research committee and was supported partially by a grant from the Department of Health.

1 Gardner MJ. Review of reported increases of childhood cancer rates in the vicinity of nuclear installations in the UK. $\mathcal{R} R$ Statist Soc (A) 1989;152 307-25.

2 Black D. Investigation of the possible increased incidence of cancer in West Cumbria. London: HMSO, 1984

3 Gardner MJ, Hall AJ, Snee MP, Downes S, Powell CA, Terrell JD. Methods and basic data of case-control study of leukaemia and lymphoma among young people near Sellafield nuclear plant in West Cumbria. Br Med $\mathcal{f}$ young people near
1990;300:429-34.
4 Breslow NE, Day NE. Stutistical methods in cancer research. Vol 1. The analysis of case-control studies. Lyon: International Agency for Research on Cancer, 1980:Chapters $V$ and VII

5 Anonymous. EGRET. Seattle: Statistics and Epidemiology Research Corporation, 1989.

6 Hall EJ. Radiobiology for the radiologist. Philadelphia: Harper and Row, 1978: Chapter 19.

7 Doll R. The epidemiology of childhood leukaemia. $\mathcal{F} R$ Statist Soc $(A)$ 1989;152:341-51.

8 Ishimaru T, Ichimaru M, Mikami M. Leukaemia incidence among individuals exposed in utero, children of atomic bomb survivors and their controls, Hiroshima and Nagasaki, 1945-79. Hiroshima: Radiation Effects Research Foundation, 1981. (RERF Technical Report 11-81.)

9 Nomura T. Parental exposure to $x$ rays and chemicals induces heritable tumours and anomalies in mice. Nature 1982;296:575-7.

10 Committee on Medical Aspects of Radiation in the Environment. Investigation of the possible increased incidence of leukaemia in young people near Dounreay of the posstble increased incidence of leukaemia in young people near D
Nuclear Establishment, Caithness, Scotland. London: HMSO, 1988.

11 Committee on Medical Aspects of Radiation in the Environment. Report on the incidence of childhood cancer in the West Berkshire and North Hampshire area, in incidence of childhood cancer in the West Berkshire and North Hampshire area, in which are situated the Atomic Weapons Research Establishment, Alderna

12 Gardner MJ, Hall AJ, Downes S, Terrell JD. Follow up study of children born to mothers resident in Seascale, West Cumbria (birth cohort). Br Med $\mathcal{F}$ 1987;295:822-7.

13 Gardner MJ, Hall AJ, Downes S, Terrell JD. Follow up study of children born elsewhere but attending schools in Seascale, West Cumbria (schools cohort). Br.Med f 1987;295:819-22.

14 Beral V, Inskip H, Fraser P, Booth M, Coleman D, Rose G. Mortality of employees of the United Kingdom Atomic Energy Authority, 1946-1979. BrMed f 1985;291:440-7.

15 Beral V, Fraser P, Carpenter L, Booth M, Brown A, Rose G. Mortality of employees of the Atomic Weapons Establishment, 1951-82. Br Med $\mathcal{F}$ 1988;297:757-70.

16 Kinlen LJ. The relevance of population mixing to the aetiology of childhood leukaemia. In: Crosbie WA, Gittus JH, eds. Medical response to effects of leukising radiation. London: Elsevier, 1989:272-8.

17 Cook-Mozaffari P, Darby S, Doll R. Cancer near potential sites of nuclear installations. Lancet 1989;1i:1145-7.

18 International Commission on Radiological Protection. Recommendations of the International Commission on Radiological Protection. Oxford: Pergamon Press, 1966. (ICRP Publication Number 9.)

19 National Radiological Protection Board. Interim guidance on the implications of recent revisions of risk estimates and the ICRP 1987 Como statement. London: HMSO, 1987:4. (NRPB-G59.)

20 National Radiological Protection Board. Radiation exposure of the UK population-1988 review. London: HMSO, 1989:86. (NRPB-R227.)

21 Smith PG, Douglas AJ. Mortality of workers at the Sellafield plant of British Nuclear Fuels. Br Med J 1986;293:845-54.

(Accepted 29 fanuary 1990)
MRC Environmental

Epidemiology Unit

(University of

Southampton),

Southampton General

Hospital, Southampton SO9 4XY

Martin J Gardner, PHD, professor of medical statistics

Andrew J Hall, MRCP, epidemiologist

Michael P Snee, FRCR, radiotherapist

Susan Downes, BSC, research assistant

Caroline A Powell, MSC, research assistant

\section{West Cumbria Health} Authority, West

Cumberland Hospital, Whitehaven, Cumbria CA28 8JG

John D Terrell, FFCM, former district medical officer

Correspondence to: Professor Gardner.

BrMed f 1990;300:429-34

\title{
Methods and basic data of case-control study of leukaemia and lymphoma among young people near Sellafield nuclear plant in West Cumbria
}

\author{
Martin J Gardner, Andrew J Hall, Michael P Snee, Susan Downes, Caroline A Powell, \\ John D Terrell
}

\section{Abstract}

Objective-To examine whether the observed excess of childhood leukaemia and lymphoma near the Sellafield nuclear plant is associated with established risk factors or with factors related to the plant.

Design-A case-control study.

Setting - West Cumbria health district.

Subjects -52 Cases of leukaemia, 22 of nonHodgkin's lymphoma, and 23 of Hodgkin's disease occurring in people born in the area and diagnosed there in 1950-85 under the age of 25 and 1001 controls matched for sex and date of birth taken from the same birth registers as the cases.

Main outcome measures-Antenatal abdominal $x$ ray examinations, viral infections, habit factors, proximity to and employment characteristics of parents at Sellafield.

Results - Ascertainment of cases through multiple sources was as complete as possible, and the diagnosis was established for nearly all cases from hospital records and by independent pathological review when suitable material $(60 \%$ (58) of cases) was available. Identification and tracing of the parents of cases and controls enabled questionnaires to be forwarded to $730(66 \%)$, and $467(64 \%)$ of the questionnaires were returned completed. Obstetric records were located for $481(44 \%)$ of the relevant births, more frequently in recent years. Linkage of study subjects to the Sellafield workforce file enabled dates of employment and records on external doses of whole body ionising radiation to be obtained. Concordance of information from duplicate sources (when available) was reasonably high with no indications of bias.

Conclusion-Overall the collected data were sufficiently reliable for detailed analysis and careful interpretation.

\section{Introduction}

In November 1983 a Yorkshire Television programme (Windscale: the Nuclear Laundry) suggested that there was an excess incidence of childhood leukaemia and other cancers in the village of Seascale and some neighbouring areas close to the Sellafield nuclear site on the coast of Cumbria. The Black committee (of which MJG was a member) was set up to investigate this suggestion and made recommendations for four epidemiological studies related to childhood cancer in West Cumbria. ${ }^{1}$ Three of these, two reporting the occurrence of cancer among children born or attending 
schools in Seascale ${ }^{23}$ and one examining the distribution of childhood cancer in the Northern region, ${ }^{4}$ have been published.

Part of the rationale behind the recommendations was that geographical studies of incidence or mortality include little or no direct information on individuals with or without the disease. Thus the Black report recommended that "a study should be carried out on the records of those cases of leukaemia and lymphoma which have been diagnosed among young people up to the age of 25, resident in West Cumbria. These cases should be compared with suitable controls in respect of factors that could be relevant to the development of leukaemia and lymphoma."

This study, carried out in response to this recommendation, addressed the following hypotheses: firstly, that the raised rates within the area are due to a high frequency of known causes of childhood leukaemia and lymphoma and, secondly, that the raised rates are associated with some aspect or aspects of the Sellafield plant. More specifically, the identified cases and controls served the following four predetermined study aims.

(1) To examine maternal exposure to medical $x$ rays and the occurrence of infectious diseases during pregnancy, since the former is an accepted cause of leukaemia in children ${ }^{5-9}$ and the latter is suspected..$^{9-11}$

(2) To examine the geographical distribution at birth, in particular to obtain information on proximity to Sellafield.

(3) To examine habits that might have enhanced exposure to radionuclides released from Sellafield - for example, consumption of fresh seafood and playing on the beach.

(4) To examine the occupations of the parent population, in particular to obtain information on employment at Sellafield and occupational radiation dose.

Using West Cumbria for the study included a larger area than that (mainly Seascale) in which the excess incidence (mainly of leukaemia) had been reported. ${ }^{\prime}$ Nevertheless, it contains stretches of coastline, including estuaries, where concerns had been

TABLE I-Numbers of cases by sex, independent pathological review, and diagnostic category

\begin{tabular}{|c|c|c|c|c|c|c|}
\hline \multirow[b]{2}{*}{ Diagnosis } & \multirow{2}{*}{$\begin{array}{c}\text { Classification } \\
\text { number }\end{array}$} & \multicolumn{2}{|c|}{ Sex } & \multicolumn{2}{|c|}{ Independent pathological review } & \multirow[b]{2}{*}{ Total } \\
\hline & & Male & Female & Yes & No & \\
\hline Leukaemia & & 30 & 22 & 25 & 27 & 52 \\
\hline Lymphoid & 1 & 17 & 13 & 15 & 15 & 30 \\
\hline Non-lymphoid & $2+3$ & 11 & 8 & 10 & 9 & 19 \\
\hline Unspecified & 4 & 2 & 1 & 0 & 3 & 3 \\
\hline Lymphoma & & 20 & 25 & 33 & 12 & 45 \\
\hline Hodgkin's disease & 5 & 9 & 14 & 18 & 5 & 23 \\
\hline Non-Hodgkin's & 6 & 11 & 8 & 13 & 6 & 19 \\
\hline Histiocytosis X & 29 & 0 & 3 & 2 & 1 & 3 \\
\hline
\end{tabular}

$\star$ See annex 1 of Draper et al. ${ }^{12}$

TABLE II - Numbers of cases by diagnostic category, calendar period, and age at diagnosis

\begin{tabular}{lccc}
\hline Group & Leukaemia & $\begin{array}{c}\text { Non-Hodgkin's } \\
\text { lymphoma }\end{array}$ & $\begin{array}{c}\text { Hodgkin's } \\
\text { disease }\end{array}$ \\
\hline Period of diagnosis & & & \\
$\quad 1950-4$ & 4 & 3 & 1 \\
$1955-9$ & 7 & 2 & 3 \\
$1960-4$ & 8 & 4 & 2 \\
$1965-9$ & 7 & 3 & 2 \\
$1970-4$ & 10 & 3 & 7 \\
$1975-9$ & 8 & 3 & 6 \\
$1980-5$ & 17 & 6 & 0 \\
Age (years) at diagnosis & 13 & 2 & 1 \\
$\leqslant 4$ & 7 & 3 & 0 \\
$5-9$ & 12 & 7 & 9 \\
$10-14$ & 3 & 4 & 13 \\
$15-19$ & $5-24$ & 22 & 23 \\
\hline Total & 52 & & \\
\hline
\end{tabular}

raised about potential risks from radiation contamination as well as inland regions away from the coast. In addition, West Cumbria was chosen partly to cover the places of residence of the Sellafield workforce. NonHodgkin's lymphomas were included because there is evidence of some relation with radiation and also because non-Hodgkin's lymphoma could have been confused with leukaemia during the early years of this study. Hodgkin's disease was included, although it is not thought to be related to radiation. Thus we decided in advance to examine leukaemia and non-Hodgkin's lymphoma separately from Hodgkin's disease in the main analysis and also to look at Seascale particularly. This paper reports the methods and some basic data of the case-control study.

\section{Methods}

\section{IDENTIFICATION OF STUDY SUBJECTS}

\section{The cases}

We started by compiling a definitive list of cases of leukaemia and lymphoma diagnosed from 1 January 1950 to 31 December 1985 among people aged under 25 years with a residential address in the area served by West Cumbria Health Authority. This area runs down the coast from above Maryport to Millom, including Workington, Whitehaven, and Seascale, and inland for some $20 \mathrm{~km}$. Various sources were used to identify the relevant cases, and other tumours, includingnotification of cases to the Black inquiry; case records from a childhood cancer survey initiated in West Cumbria at the time of the Black inquiry; pathology records using the histological diagnosis card index at the West Cumberland Hospital; death entries for 1950-8 for the registration divisions of Cumbria, Newcastle, and Manchester (the last two because patients are referred to these centres from West Cumbria); death certificates for 1959 onwards for Cumbria at the health authority office in Carlisle; death entries for districts that could have registered West Cumbrian deaths at the Office of Population Censuses and Surveys; death certificates mentioning leukaemia from 1959 onwards (Dr L J Kinlen, personal communication); cancer registrations in the Northern region children's malignant disease registry; cancer registrations in the Northern region cancer registry from 1969 onwards; circular letters to general practitioners in West Cumbria asking them to notify any known eligible cases; preschool illness notifications in the Flatt Walks Clinic records in Whitehaven; and cancer registrations held by the Oxford Childhood Cancer Survey (Dr G J Draper, personal communication).

For this report we included only cases in people born and diagnosed in West Cumbria and omitted six cases of leukaemia and eight of lymphoma in people born outside. The residential addresses were determined from hospital records, questionnaires, death certificates, or the Cumbria Family Practitioner Committee records.

Table I shows the numbers of cases by sex and diagnostic category, where diagnosis was taken in order from the following sources as available: pathological review, hospital records, cancer registrations, and death certificates. Thus 52 cases of leukaemia, 22 of non-Hodgkin's lymphoma, and 23 of Hodgkin's disease make up the main study group; 95 other tumours were also identified and subjected to pathological review but are not reported on further in this paper. Table II shows the numbers of cases by diagnostic category, calendar period, and age at diagnosis. The pattern of cases over time was fairly consistent, and the decreasing numbers of cases of leukaemias and increasing numbers of cases of Hodgkin's disease with age concur with known relations. 
TABLE III - Numbers of cases of leukaemia and lymphoma by numbers of controls of area or local type

\begin{tabular}{|c|c|c|c|c|c|c|}
\hline \multirow[b]{2}{*}{ No of controls } & \multicolumn{2}{|c|}{ Leukaemia } & \multicolumn{2}{|c|}{ Non-Hodgkin's lymphoma } & \multicolumn{2}{|c|}{ Hodgkin's disease } \\
\hline & Area & Local & Area & Local & Area & Local \\
\hline 8 & 16 & 18 & 5 & 4 & 1 & 2 \\
\hline 7 & 24 & 16 & 5 & 7 & 6 & 4 \\
\hline 6 & 4 & 8 & 9 & 6 & 5 & 8 \\
\hline 5 & 5 & 7 & 2 & 3 & 7 & 6 \\
\hline 4 & 3 & 1 & - & 2 & 3 & 2 \\
\hline 3 & - & 1 & 1 & - & 1 & 1 \\
\hline 2 & - & - & - & - & - & - \\
\hline 1 & - & 1 & - & - & - & - \\
\hline 0 & - & - & - & - & - & - \\
\hline \multirow{2}{*}{$\begin{array}{l}\text { Cases } \\
\text { Controls }\end{array}$} & 52 & 52 & 22 & 22 & 23 & 23 \\
\hline & 357 & 347 & 142 & 140 & 130 & 133 \\
\hline Both area and local controls & \multicolumn{2}{|c|}{140} & \multicolumn{2}{|c|}{56} & \multicolumn{2}{|c|}{52} \\
\hline Total controls & \multicolumn{2}{|c|}{564} & \multicolumn{2}{|c|}{226} & \multicolumn{2}{|c|}{211} \\
\hline
\end{tabular}

\section{The controls}

The selection of controls was from registers of live births at the Office of Population Censuses and Surveys. Two groups of eight controls of the same sex as the case were taken from the register into which the case's birth was entered. The appropriate register was identified with the help of the National Health Service central register when necessary.

For one group (area controls) searches were made backwards and forwards from the case's entry in the birth register until the nearest four appropriate controls in each direction were found. Only births to mothers with a West Cumbria address were included. For the second group (local controls) the residence of their mothers was matched for residence (civil parish) of the mothers of the case at the date of birth, although otherwise the procedure was as for the first group. Date of birth matching was within six months for $99 \%$ of area controls and $92 \%$ of local controls. The area controls were particularly relevant to the geographical analysis mentioned in study aim 2, although their selection was stratified by birth registration district.

There was thus effectively matching of controls on sex and date of birth, and each group of controls was registered in the same district or subdistrict (12 in number over the 35 years) as their case. This method of control selection was used for ease of procedure, to obtain close matching for date of birth, and because there is not thought to be an area of residence bias in the order of births within any register. The same individual could have been used as a control in both groups. Thus, if any one of the four adjacent births of the same sex to a case was also from the same civil parish then this control would have been in each group.

For each control a check was made at the National Health Service central register to see whether they were still alive and for any cancer registration particulars. Thirty four controls who were found to have died (25 infant deaths) before the date of diagnosis of their matched cases were excluded, but no controls were found to have been registered with cancer by, or died from cancer within 10 years of, the date of diagnosis of their matched case.

Additionally, to have the potential to be a case in this study at the appropriate time, controls had to have been resident in West Cumbria at the date of diagnosis of their associated case. This information was determined initially at the National Health Service central register by reference to the family practitioner committee area of registration at the appropriate date. In total 195 controls registered outside Cumbria were thus excluded. Residence particulars for controls with a Cumbrian registration or no registration were examined in questionnaires sent to parents (see later) and a further 13 excluded. Those left out from the questionnaire part of the study, together with non-responders, were reviewed within the Cumbria Family Practitioner Committee records at the relevant date with no subsequent exclusions.

Table III shows the numbers of cases by their number of controls. Although not shown in the table, we were able originally to select from the birth registers eight area and eight local controls for all cases except one of leukaemia. When the other criteria for control definition were incorporated the numbers of included controls per case decreased as shown in the table. In total 1001 of 1243 originally selected controls for the 97 cases remained. Of these 248 served as both area and local controls.

\section{Parents of cases and controls}

Identifying particulars for the parents of each case and control were found from the child's birth certificate and elsewhere, such as obstetric and general medical records. The aim was to identify uniquely the parents in the National Health Service central register and thus ascertain whether they were still alive. For parents found to be alive, and if they were eligible for the questionnaire part of the study (see below), their current family practitioner committee registration was traced to enable them to be contacted through their own general practitioner. Local family practitioner committees were able to identify the parent's general practitioner's name and address, as well as the parent's recorded residential particulars.

Table IV shows the numbers of mothers and fathers traced as being alive in the records of the National Health Service central register. Of the 97 cases the mother was alive for 81 , and among the remaining 16 cases 6 of the fathers were alive. In 10 cases both parents were recorded as having died.

TABLE IV -Numbers of cases of leukaemia and lymphoma by parenta vital status at date of study

\begin{tabular}{lrcc}
\hline Parental vital status & Leukaemia & $\begin{array}{c}\text { Non-Hodgkin's Hodgkin's } \\
\text { lymphoma }\end{array}$ & disease \\
\hline Mother & & & \\
$\quad$ Alive & 45 & 18 & 18 \\
$\quad$ Dead & 7 & 4 & 5 \\
Father (only when mother dead) & & 1 & 2 \\
$\quad$ Alive & 3 & 3 & 3 \\
Dead & 4 & & \\
\hline
\end{tabular}

DATA COLLECTED ON CASES AND CONTROLS

Hospital records

Hospital records were examined for two purposes: firstly, to obtain detailed information on the case's diagnosis and, secondly, to extract data from the relevant obstetric notes on the mother's pregnancy for both cases and controls.

Hospital records were available for all but two of the cases. As well as abstracting relevant clinical details, we ascertained whether or not a histological diagnosis had been made and whether histological material was available. When material was available the cases were the subject of an independent pathological review for the purposes of the Northern region children's malignant disease registry (Drs $M$ Reid and A Malcolm, personal communication) and we used their results in our classification. Table I shows the numbers of cases whose diagnoses were established through the independent pathological review: 25 (48\%) of the leukaemias and $33(73 \%)$ of the lymphomas. In none of these was a major change in classification made as a result.

Antenatal data were available from obstetric records on the mothers of $35(36 \%)$ of the cases and $446(45 \%)$ of the controls. We extracted details on exposure to $x$ rays during the pregnancy, including parts of the body examined and dates. For abdominal $x$ ray examinations 
the number and type of examination were also noted. We also obtained any recorded information on viral infections that the mother suffered during pregnancy - for example, chickenpox, influenza, or rubella. Some further data, such as birth weight, were also collected. For those mothers who had had their babies at home we could not obtain any documents on the pregnancy.

\section{Questionnaire}

Procedure-The study included a questionnaire, with information being sought directly from parents of cases and controls. This was carried out through parents' general practitioners. The questionnaire was sent to the case's mother if she was still living and her current residence could be established. For such cases the questionnaire was sent to the associated controls' mothers if they were traced as being alive and registered with a general practitioner. For other cases and their controls the questionnaires were forwarded to their fathers if registered. In this way responses from within case-control sets were obtained from parents of the same sex. When both of a case's parents were dead or untraced questionnaires were not sent for either the cases or their controls.

The National Health Service central register posted the questionnaires together with covering letters to the family practitioner committee and the general practitioner explaining the study and asking their cooperation. Also included were a letter and questionnaire to be addressed to the parent by the family practitioner committee or general practitioner. The general practitioner was asked to return an "action slip" to let us know what he or she had done. In particular, the general practitioners were asked to consider whether there were any reasons for not posting the questionnaire to the parent-for example, if the parent was known to be ill or the questionnaire might cause unacceptable distress - and if so to return the package to the central register with a note to this effect. Before the questionnaires were posted the district medical officer (JDT) wrote to all general practitioners in West Cumbria explaining the study and requesting their cooperation, and this was accompanied by a request in the local newspaper seeking parents' participation. If replies were not received from parents within three months a reminder package was sent, with a "reply slip" for the parents to return if they did not want to complete the questionnaire. No further attempts were made to obtain replies.

Content-The purpose of the questionnaire was both to obtain information which had been partly collected through the methods described earlier but now directly from the parents and to request data otherwise unavailable. Thus we asked the parent about antenatal care, including $x$ ray examinations and infectious illnesses, during the relevant pregnancy. Also we asked for the residential and occupational histories of both parents from the time they left school, as well as the residential history of their child. Other data requested included the child's birth weight, childhood activities on the beach and in the Lake District, and family habits in eating fresh seafood and home grown vegetables.

Response-Table $\mathrm{V}$ shows the numbers of questionnaires sent to general practitioners and to parents of cases and controls with their outcome. For the 97 cases 86 questionnaires were forwarded to general practitioners and $76(78 \%)$ to parents. Of the latter $64(84 \%)$ were returned completed by the relevant parent and a further $5(7 \%)$ were returned without being filled out. For the 1001 controls 727 questionnaires were forwarded to general practitioners and $654(65 \%)$ to parents. Of the latter $403(62 \%)$ were returned completed by the relevant parent and a further $44(7 \%)$
TABLE V - Numbers of questionnaires forwarded to general practitioners and parents and whether or not completed and returned to Medical Research Council (MRC)

\begin{tabular}{lcccc}
\hline & \multicolumn{4}{c}{ Cases } \\
\cline { 2 - 4 } Questionnaire & Leukaemia & $\begin{array}{c}\text { Non-Hodgkin's } \\
\text { lymphoma }\end{array}$ & $\begin{array}{c}\text { Hodgkin's } \\
\text { disease }\end{array}$ & Controls \\
\hline Not forwarded to GP & 4 & 3 & $4^{\star}$ & 274 \\
Forwarded to GP & 48 & 19 & 19 & 727 \\
$\begin{array}{l}\text { Forwarded to parent } \\
\text { Returned to MRC }\end{array}$ & 42 & 18 & 16 & 654 \\
$\quad$ from mothers/ & & & & \\
$\quad$ fathers): & $35 / 2$ & $12 / 1$ & $13 / 1$ & $392 / 11$ \\
$\quad$ Completed & $2 / 0$ & $2 / 0$ & $1 / 0$ & $39 / 5$ \\
$\quad$ Not completed & 3 & 3 & 1 & 207 \\
Not returned to MRC & 3 & & & \\
\end{tabular}

*The mother of one case of Hodgkin's disease, although believed alive (table IV), could not be traced and the father had died.

were returned without being filled out. There was thus a higher response rate for cases than for controls, with the overall proportion of questionnaires forwarded being $66 \%$, of which $64 \%$ were completed. A total of 29 parents replied saying that they did not want to complete the questionnaire. We were not informed of the general practitioner's action for only one of the 86 cases and $17(2 \%)$ of the 727 controls.

\section{Geographical data}

One aspect of the study was to compare the geographical distributions of the cases and controls in relation to Sellafield. For this purpose residential addresses at birth for cases and controls were identified on Ordnance Survey maps, and national grid references accurate to 100 metre squares were obtained for most $(87 \%)$ addresses. For the remainder the accuracy was less, and in some instances addresses were untraceable, mainly those from the earlier years covered by the study. This method allowed a modified approach to the geography of cases rather than simply examining routine mortality and cancer registration statistics. ${ }^{13-15}$. The differences in approach are at least twofold: firstly, the use of controls rather than census figures to represent the population and, secondly, location at birth rather than diagnosis. In fact, the cases tended to be diagnosed at the same address or at one close to where they had been born.

\section{Occupational data}

Occupational data on the parents of cases and controls were obtained from three different sources. Firstly, we abstracted parental (mainly fathers') occupations from the birth certificates of their children. Secondly, we obtained occupational histories by questionnaire. These sets of data were coded to both occupation and industry using standard classifications $^{16} 17$ with local additions. Thirdly, we crossmatched our computer file of study subjects with that of the past and present Sellafield workforce to indentify people who appeared on both files. This linkage was carried out using surname, initials, and date of birth, with incorporation of forenames and National Health Service numbers when available on both files. For those subjects identified as having worked at Sellafield, British Nuclear Fuels subsequently supplied us with dates of employment at the site and external whole body ionising radiation dosimetry on an annual basis. The radiation dose in each year had been estimated from monitoring with dose meters worn on the trunk, and our figures came from the data on which satisfactory quality checks have been reported ${ }^{18}{ }^{19}$ No details of exposure to internally incorporated radionuclides are yet available, though they will become so. This information was used to examine the relative frequency of employment and radiation exposure at Sellafield among parents of cases and controls and also to examine relations with other occupations and industries. 
Table VI shows the extent to which job data were available. Job descriptions were entered on birth certificates for most fathers $(97 \%)$ but for only few mothers (about $2 \%$, as expected from birth registration practice). Data from questionnaires, however, were obtained to a similar degree on both fathers and mothers (about $40 \%$ overall).

\section{CONCORDANCE OF DATA}

Antenatal $x$ ray exposure - Table VII shows data on abdominal $x$ ray examinations during pregnancy obtained from hospital obstetric records compared with data from the questionnaire for cases and controls separately. Although the overall agreement between the sources was reasonable, there were notable discrepancies - for example, out of 35 documented $x$ ray examinations $15(43 \%)$ were not recalled by the mother. There was, however, no evidence of any bias between mothers of cases and controls in their recall.

Employment at Sellafield - Table VIII shows findings on fathers' employment at Sellafield at the birth of

TABLE VI-Numbers of cases and controls by diagnostic category and availability of parental employment data by source

\begin{tabular}{|c|c|c|c|c|}
\hline \multirow{2}{*}{$\begin{array}{l}\text { Presence of } \\
\text { employment data } \\
\text { and source }\end{array}$} & \multicolumn{3}{|c|}{ Cases } & \multirow[b]{2}{*}{ Controls } \\
\hline & Leukaemia & $\begin{array}{l}\text { Non-Hodgkin's } \\
\text { lymphoma }\end{array}$ & $\begin{array}{l}\text { Hodgkin's } \\
\text { disease }\end{array}$ & \\
\hline \multirow{2}{*}{\multicolumn{5}{|c|}{ Birth certificate }} \\
\hline \multicolumn{4}{|l|}{ Father } & \\
\hline Yes & 48 & 20 & 23 & 969 \\
\hline No & 4 & 2 & 0 & 32 \\
\hline \multicolumn{5}{|l|}{ Mother } \\
\hline Yes & 2 & 1 & 0 & 17 \\
\hline No & 50 & 21 & 23 & 984 \\
\hline \multicolumn{5}{|l|}{ Questionnaire } \\
\hline \multicolumn{5}{|l|}{ Father } \\
\hline Yes & 36 & 12 & 13 & 386 \\
\hline No & 16 & 10 & 10 & 615 \\
\hline \multicolumn{5}{|l|}{ Mother } \\
\hline Yes & 35 & 10 & 13 & 378 \\
\hline No & 17 & 12 & 10 & 623 \\
\hline
\end{tabular}

TABLE VII - Data on maternal abdominal $x$ ray examinations during pregnancy from hospital records and postal questionnaires among cases and controls

\begin{tabular}{|c|c|c|c|c|}
\hline \multirow{2}{*}{$\begin{array}{l}X \text { ray examination } \\
\text { according to } \\
\text { hospital record }\end{array}$} & \multicolumn{3}{|c|}{$\begin{array}{l}X \text { ray examination according to } \\
\text { questionnaire response }\end{array}$} & \multirow[b]{2}{*}{ Total } \\
\hline & Yes & No & No response & \\
\hline \multicolumn{5}{|c|}{ Cases } \\
\hline Yes & 2 & 2 & 1 & 5 \\
\hline & 1 & 20 & 9 & 30 \\
\hline No records & 5 & 30 & 27 & 62 \\
\hline Total & 8 & 52 & 37 & 97 \\
\hline \multicolumn{5}{|c|}{ Controls } \\
\hline Yes & 18 & 13 & 29 & 60 \\
\hline No & 8 & 171 & 207 & 386 \\
\hline No records & 9 & 155 & 391 & 555 \\
\hline Total & 35 & 339 & 627 & 1001 \\
\hline
\end{tabular}

TABLE VIII-Data on paternal employment at Sellafield at child's birth from birth certificate, questionnaire, and from British Nuclear Fuels file of past and present workers for cases and controls

\begin{tabular}{|c|c|c|c|c|c|c|}
\hline \multirow{3}{*}{$\begin{array}{l}\text { Employment at } \\
\text { Sellafield } \\
\text { according to } \\
\text { British Nuclear } \\
\text { Fuels file }\end{array}$} & \multicolumn{6}{|c|}{ Employment at Sellafield according to: } \\
\hline & \multicolumn{3}{|c|}{ Birth certificate } & \multicolumn{3}{|c|}{ Questionnaire } \\
\hline & Yes & No & $\begin{array}{l}\text { Not } \\
\text { recorded }\end{array}$ & Yes & No & $\begin{array}{l}\text { No } \\
\text { response }\end{array}$ \\
\hline \multicolumn{7}{|c|}{ Cases } \\
\hline Yes & 9 & 0 & 1 & 5 & 0 & 5 \\
\hline No & 1 & 75 & 2 & 0 & 36 & 42 \\
\hline Trace not possible & 1 & 1 & 7 & 1 & 2 & 6 \\
\hline \multicolumn{7}{|c|}{ Controls } \\
\hline Yes & 83 & 3 & 7 & 55 & 3 & 35 \\
\hline & 5 & 759 & 49 & 0 & 224 & 589 \\
\hline Trace not possible & 7 & 53 & 35 & 4 & 21 & 70 \\
\hline
\end{tabular}

their children from the three varying sources. There was good general agreement among the different datasets. For example, for the 10 cases identified as employed at Sellafield by computer linkage this was agreed when suitable data were available from the other two sources. One case of Hodgkin's disease was not linked to Sellafield, although employment there was recorded on the birth certificate. Concordance on Sellafield employment status was also high among controls. Agreement for non-Sellafield occupation and industry data between birth certificates and questionnaires was also high, although results are not shown here.

\section{Conclusions}

We recognised at the outset that obtaining complete information on cases diagnosed over a 35 year period and their contemporary controls would be impossible owing to the lack of historical records and the difficulty of tracing parents. This was partly the rationale for taking eight area and eight local controls to allow for some attrition. Cases were ascertained from multiple overlapping sources and their identification was probably as complete as possible. Information on their diagnosis was available almost always from medical records and in over half was subject to independent pathological review. Obstetric records on the mothers of the cases and controls were identified for fewer than half the births and information was necessarily less complete in earlier years.

The level of tracing of vital status and current whereabouts of the parents was quite high, and questionnaires were posted, mainly to mothers, through their general practitioners for $90 \%$ of eligible subjects. The response rate for completed questionnaires overall, after one reminder, was $64 \%$ but higher for cases than controls. Geographical data on address at birth were coded to grid references with a high degree of accuracy. Occupational and industrial data on most parents were collected from at least one of three sources: birth certificates, questionnaires, and the Sellafield file on the past and present workforce. Annual recordings of the external dose of whole body ionising radiation from personal dose meters worn on the trunk were obtained from an extension of the same databank as used for the follow up study of Sellafield workers. ${ }^{18} 19$

When information was available from more than one source the concordance was generally high - for example, it was high for occupation and social class but less so for exposure to $x$ rays and viral infections. When there was disagreement there were no real indications of biased responses between cases and controls. For data where duplicate sources did not exist it was possible to be more certain of previously documented information, such as parental age, than of questionnaire responses on, for example, shellfish eating habits. Information on a number of factors for some cases and controls was lacking altogether because documents were missing or parents could not be traced or did not respond to the questionnaire. Overall, however, the data were sufficiently reliable for detailed analysis and careful interpretation (see accompanying paper, p 423). ${ }^{20}$

We thank the registration division of the Office of Population Censuses and Surveys, the West Cumbria Health Authority, the Cumbrian Family Practitioner Committee, and other sources mentioned in the text for their cooperation in identifying records on subjects included in the study; the National Health Service central register for providing follow up and tracing details and, with the generous collaboration of local general practitioners, for forwarding questionnaires to parents; the parents for completing them; the Ordnance Survey and British Nuclear Fuels for making relevant infor- 
mation available to us; and many staff of the Medical Research Council Environmental Epidemiology Unit for their help, particularly Mick Merwood for computer analyses and Gill Strange for preparing the manuscript. Professor Geoffrey Rose kindly commented on an earlier version of the paper. The study was approved by the British Medica Association ethical committee and the West Cumbria ethics of research committee and was supported partially by a grant from the Department of Health.

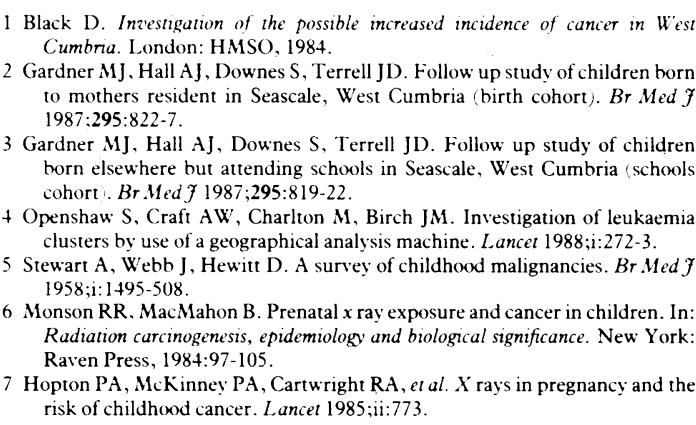
Cumbra. London: HMSO, 1984.

2 Gardner MJ. Hall AJ, Downes S, Terrell JD. Follow up study of children born to mothers resident in Seascale, West Cumbria (birth cohort). Br Med 1987:295:822-7.

Gardner MJ, Hall AJ, Downes S, Terrell JD. Follow up study of children horn elsewhere but attending schools in Seascale, West Cumbria schools cohort Br.Med f 1987;295:819-22.

+ Openshaw S, Craft AW, Charlton M. Birch JM. Investigation of leukaemia clusters by use of a geographical analysis machine. Lancet 1988;i:272-3.

5 Stewart A, Webb J, Hewitt D. A survey of childhood malignancies. Br.Med $\mathcal{J}$ 1958;i:1495-508.

Monson RR MacMahon B. Prenatal $x$ ray exposure and cancer in children. Radiation carcinogenesis, epidemiology and biological significance. New York: Raven Press, 1984:97-105.

Hopton PA, McKinney PA, Cartwright RA, et al. $X$ rays in pregnancy and the risk of childhood cancer. Lancet 1985;ii:773.

8 Knox EG, Stewart AM, Kneale GW, Gilman EA. Prenatal irradiation and childhood cancer. F Soc Radiol Prot 1987;7:3-15.

9 Doll R. The epidemiology of childhood leukaemia. $f R$ Statist Soc $(A$ 1989;152:341-51

10 Adelstein AM, Donovan JW. Malignant disease in children whose mother had chicken pox, mumps or rubella in pregnancy. Br Med f 1972;iv:629-31. 11 Fedrick J, Alberman ED. Reported influenza in pregnancy and subsequent cancer in the child. Br Med F 1972;ii:485-8.

12 Draper GJ, Birch JM, Bithell JF, et al. Childhood cancer in Britain: incidence, survival and mortality. London: HMSO, 1982. Office of Population Censuses and Surveys, Studies on Medical and Population Subjects No 37

13 Gardner MJ, Winter PD. Cancer in Cumberland during $1959-78$ with reference to cancer in young people around Windscale. Lancet 1984;i:216-7.

14 Urquhart J, Palmer M. Cutler J. Cancer in Cumbria: the Windscale connection. Lancel $1984 ; \mathrm{i}: 217-8$.

15 Craft AW, Openshaw S, Birch J. Apparent cluster of childhord malignancies in Northern England. Lancet 1984;ii: $96-7$.

16 General Register Office. Classification of Occupations, 1966. London: HMSO, 1966

17 Central Statistical Office. Standard Industrial Classification. Revised 1968 London: HMSO, 1968

18 National Radiological Protection Board. Radiation dose histories at British Nuclear Fuels plc, Sellafield. Chilton: NRPB, 1986. (NRPB-M136.

19 Smith PG, Douglas AJ. Mortality of workers at the Sellafield plant of British Nuclear Fuels. Br.Med f 1986;293:845-54.

20 Gardner MJ, Snee MP, Hall AJ, Powell CA, Downes S, Terell JD. Results of case-control study of leukaemia and lymphoma among young people near Sellafield nuclear plant in West Cumbria. Br Med F 1990;300:423-9.

Accepted 29 fanuar 1990
Departments of Child Health and Community Health, Leicester Royal Infirmary, PO Box 65 Leicester LE2 7LX A C Fenton, MRCP, research registrar in child health D J Field, DM, senior lecturer in child health

E Mason, MPHIL, research associate in community health $M$ Clarke, FFCM, professor in community health

Correspondence to: Dr Field

Br.Med f 1990;300:43+-6

\title{
Attitudes to viability of preterm infants and their effect on figures for perinatal mortality
}

\author{
A C Fenton, D J Field, E Mason, M Clarke
}

\section{Abstract}

Objective-To examine how local attitudes to management of extreme preterm labour can influence data on perinatal mortality.

Design-One year prospective study in a geographically defined population.

Setting - The 17 perinatal units of Trent region.

Patients-All preterm infants of $\leqslant 32$ weeks' gestation in the Trent region.

Interventions - Infants who had been considered viable at birth were referred for intensive care; those who had been considered non-viable received terminal care.

Main outcome measures-Whether each infant was born alive, dead, or alive but considered nonviable.

Results-Large differences were observed among units in the rates of delivery of infants of $\leqslant 27$ weeks' gestation (rates varied from $7 \cdot 2$ to 0 per 1000 births). These differences were not present in the data relating to infants of between 28 and 32 weeks' gestation. The variation seemed to result from different approaches to the management of extreme preterm labour-that is, whether management took place in a labour ward or a gynaecology ward.

Conclusions-Place of delivery of premature babies ( $\leqslant 27$ weeks' gestation) may influence classification and hence figures for perinatal mortality. In addition, the fact that the onus of judgment regarding viability and classification is often placed on relatively junior staff might also affect the figures for perinatal mortality. The introduction of a standard recording system for all infants $>500 \mathrm{~g}$ would be advantageous.

\section{Introduction}

Perinatal mortality still commands ënsiderable attention from the media, politicians, and the public in general.' In contrast, the medical profession has become increasingly unwilling to rely on its measurement for assessing perinatal care. Problems that have been identified include a lack of uniformity in assessing both viability and signs of life $^{2}$ and the influence of neonatal intensive care causing infants to be sustained beyond the perinatal period. ${ }^{3}$ We examined the extent to which variation in the management of preterm labour might influence perinatal mortality.

\section{Methods}

We undertook a one year prospective study (1 February 1987 to 31 January 1988) in the 17 perinatal units of the Trent region. Our intention was to identify all births at $\leqslant 32$ weeks' gestation. Data were collected by independent observers. Information was available from two sources.

(1) Labour ward records allowed the identification of all infants in the study group who were not referred for any neonatal care. These babies remained in the labour ward either because they were considered dead at delivery or because local policy was to give terminal care in the labour ward to infants considered nonviable. The records detailed birth weight, gestation, and whether the baby was born alive or dead. They did not indicate the criteria chosen to make these decisions or the grade of staff present at the delivery.

(2) Examination of the case notes of all babies admitted to individual neonatal units identified those infants given active care and those given terminal care.

\section{Results}

From the data it was possible to identify three groups of infants: $(a)$ those referred for active neonatal intervention; $(b)$ those considered to have shown no signs of life; and (c) those who died soon after birth either in the labour ward or after transfer to the neonatal unit for terminal care.

Table I gives the numbers of babies from each hospital who were referred for intensive care and of those considered to be dead at birth or who died without active neonatal intervention. Infants were further subdivided into those of $\leqslant 27$ weeks' gestation 